\title{
Correlation and Coefficient Studies in Lilium (Lilium spp.)
}

\author{
A. Sankari ${ }^{1 *}$, M. Anand ${ }^{2}$, B. Anita ${ }^{3}$ and R. SwarnaPriya ${ }^{1}$ \\ ${ }^{1}$ Department of Vegetable Science, HC \& RI, TNAU, Coimbatore, Tamil Nadu, India \\ ${ }^{2}$ HRS, TNAU, Yercaud, Tamil Nadu, India \\ ${ }^{3}$ ODL, TNAU, Coimbatore, Tamil Nadu, India \\ *Corresponding author
}

\section{Keywords}

Bulbs, Cut Flower, Lilium, Evaluation, path analysis

Article Info

Accepted:

25 January 2019

Available Online:

10 February 2020

\section{A B S T R A C T}

\section{Introduction}

Lilium is one of six major genera of flower bulbs (geophytes) produced worldwide (Hertogh and Nard, 1993). Lilium is a perennial ornamental crop belonging to Liliaceae has great ornamental, medicinal \& edible value is being cultivated for centuries as an ornamental plant. The genus lilium is native to Asia, Europe, \& North America in
Northen Hemisphere including 100 species (McRae, 1998). A large number of species \& varieties can be used in ornamental garden even though the lily requires a little more attention than many other bulbs. Lilies are wonderful ornamental plants with varied uses, grown in border, beds, pots and are excellent cut lowers of magnificent appearance \& beautiful colors. Its cultivation was restricting to temperate zone but now the researchers 
have made efforts and now it is being grown successfully in plains also. There is marked difference in desired plant heights at the time of flowering, total number of marketable flowers, spike length \& several other qualitative \& quantitative parameters in various cultivars of Lilium. Therefore, proper varietal evaluation for the location specific has become essential. Due to its immense importance and there is great demand of this flower the experiment was conducted to check the performance of lilium in Nilgiris of Tamil Nadu.

\section{Materials and Methods}

The trial was conducted at wood house Farm in Nilgiris District of Tamil Nadu during the Year $2016-17$ in randomized block design with three replications under protected conditions. The different types of Asiatic Liliums were collected from different sources and evaluated for their performance under Nilgiris.

The cultivars of Asiatic Lilium consisting of Black Out, Brunello, Navona. Tresor, Polyanna, Vermeer were evaluated. The experiment was conducted in Horticultural Research Station, TNAU, The Nilgiris which is located at $11.4025^{\prime} \mathrm{N}$ Latitude, $76.735^{\prime} \mathrm{E}$ Longitude and at an Altitude of $2635 \mathrm{~m}$ above Mean Sea Level. The mean annual rainfall of The Nilgiris is $1632 \mathrm{~mm}$. The average maximum and minimum temperature is $26.0^{\circ} \mathrm{C}$ and $2{ }^{\circ} \mathrm{C}$ respectively.

The average relative humidity is 75 per cent The collected varieties were planted in spacing of $15 \times 15 \mathrm{~cm}$. Five plants from each variety was taken for recording observations on biometric and flowering characters viz. plant height, number of leaves, days to bud formation, days to flowering, spike length, number of flowers per plant, flower bud length, flower duration and flower diameter was recorded and statistically analysed and the result is presented in Table.1. The data recorded were statistically analysed as per Panse and Sukhatme (1967).

\section{Results and Discussion}

The results of the experiment is presented in Table.1.Six Asiatic Liliums varieties viz., Brunello, Black Out, Navona, Tresor, Polyanna and Vermeer were evaluated under Nilgiris conditions. Significant differences were observed for all the characters studied. And the results of the experiment are presented in Table 1.

Among the six varieties, maximum plant height was recorded in cultivar Polyanna (129. $3 \mathrm{~cm})$, which was at par with that of Black Out $(120.0 \mathrm{~cm})$.whereas minimum plant height was recorded in cultivar Vermeer $(107.2 . \mathrm{cm})$. Similar variation in plant height of different varieties of Lilium was also reported by Sindhu and Singh (2012) under northern plains.

Similarly maximum number of leaves recorded in cultivar Navona (40.0) which was on par with that of Black Out (39.00), whereas, minimum number of leaves was recorded in cultivar Polyanna and Vermeer (39.00). Cultivar Navona recorded maximum leaf length of $10.9 \mathrm{~cm}$ followed by Brunello $(10.4 \mathrm{~cm})$ and minimum leaf length was recorded in Vermeer $(7.9 \mathrm{~cm})$. Similar variation in the vegetative parameters of Asiatic lilium was also reported by Pandey et al., (2008) and Deka et al., (2010). Differences in vegetative growth characters of different growth cultivars may be due to varied growth rate and their genetic make ups as a result, variation in phenotypic expression are expected to occur. Similar results with vegetative characters were also reported by Mishra (1997). 
Similar variation in the vegetative parameters of Asiatic Lilium was also reported by Dwibedi et al., (2002); Pandey et al., (2008) and Deka et al., (2010). Difference in vegetative growth characters of different cultivars may be due to varied growth rate and their genetic make ups as a result, variation in phenotypic expression are expected to occur. Similar results with respect to vegetative characters were also observed by Mishra (1997).

The perusal of data on flowering characters indicates that Tresor took minimum days for flowering (116 days) followed by Polyanna (118days).While Vermeer took maximum days for flowering (140 days).Findings of the present study are in close agreement with Dhiman (2003) who observed significant variation among lilium hybrids under Kullu condition. The variation in number of days taken for flowering was primarily due to the genetic constitution of various cultivars and prevailing environmental conditions during the period of crop growth.

Number of flower buds per shoot is an important character which decides the cost of the flowering shoot. Generally more flower buds per shoot are preferred. Number of flowers per flowering shoot is also an important character for cut flower production. In the present study, highest number of buds was recorded in cultivar Tresor (5.3) followed by Navona (4.0). whereas minimum number of buds (2.0) was recorded in cultivar Polyanna. Result of the present study is in conformity with the findings of Deka et al., (2010), Srinivas (2002) and Srinivas (2003) who reported similar variation among Lilium cultivars with respect to this parameter. Wide variation in floral parameters due to varieties has also been reported by Dhiman (2003)

Flower bud length and width in different Asiatic lily varieties differed significantly. Maximum length and width were recorded in Tresor $(19.9 \mathrm{~cm}$ and $19.7 \mathrm{~cm})$. While the minimum length and width was recorded in Vermeer. Size of the flower also contributes to the quality of the flowering shoot and biggest buds in a flowering shoots are always preferred. It may be concluded that variation in diameter of flower mainly due to the genetic make up which might have been further modified by the environmental condition prevailing during the time of experiment.

Table.1 Performance of Asiatic Liliums under Nilgiris

\begin{tabular}{|l|l|l|l|l|c|c|c|c|c|}
\hline S.No. & Varieties & $\begin{array}{c}\text { Plant } \\
\text { height }\end{array}$ & $\begin{array}{c}\text { Number } \\
\text { of leaves }\end{array}$ & $\begin{array}{c}\text { Leaf } \\
\text { length(cm) }\end{array}$ & $\begin{array}{c}\text { Days to } \\
\text { flowering }\end{array}$ & $\begin{array}{c}\text { Spike } \\
\text { length } \\
\text { (cm) }\end{array}$ & $\begin{array}{c}\text { Number of } \\
\text { flowers per } \\
\text { plant }\end{array}$ & $\begin{array}{c}\text { Flower } \\
\text { bud length } \\
\text { (cm) }\end{array}$ & $\begin{array}{c}\text { Flower } \\
\text { diameter } \\
\text { (cm) }\end{array}$ \\
\hline $\mathbf{1 .}$ & Black out & 120.0 & 39.0 & 8.3 & 135 & 43.0 & 4.0 & 18.0 & 15.3 \\
\hline $\mathbf{2 .}$ & Brunello & 104.6 & 36.0 & 10.4 & 120 & 48.6 & 3.0 & 16.9 & 16.7 \\
\hline $\mathbf{3 .}$ & Navona & 110.0 & 40.0 & 10.9 & 125 & 47.1 & 4.0 & 15.7 & 19.2 \\
\hline $\mathbf{4 .}$ & Tresor & 109.7 & 38.0 & 9.5 & 116 & 52.4 & 5.3 & 19.9 & 19.7 \\
\hline $\mathbf{5 .}$ & Polyanna & 129.3 & 33.0 & 9.8 & 118 & 48.1 & 2.0 & 18.9 & 16.9 \\
\hline $\mathbf{6 .}$ & Vermeer & 107.2 & 33.0 & 7.9 & 140 & 49.3 & 3.0 & 16.4 & 16.1 \\
\hline & SED & $\mathbf{2 . 6 4}$ & $\mathbf{2 . 1 0}$ & $\mathbf{0 . 1 6}$ & $\mathbf{6 . 4 9}$ & $\mathbf{1 . 1 5}$ & $\mathbf{0 . 1 6}$ & $\mathbf{0 . 2 2}$ & $\mathbf{0 . 9 0}$ \\
\hline & CD at 5\% & $\mathbf{5 . 8 9}$ & $\mathbf{4 . 7 0}$ & $\mathbf{0 . 3 7}$ & $\mathbf{1 4 . 4 6}$ & $\mathbf{2 . 5 7}$ & $\mathbf{0 . 3 6}$ & $\mathbf{0 . 4 9}$ & $\mathbf{2 . 0 2}$ \\
\hline
\end{tabular}


Table.2. Simple correlation co- efficients between yield characters in Lilium

\begin{tabular}{|c|c|c|c|c|c|c|c|c|c|}
\hline & & $\begin{array}{c}\text { Plant } \\
\text { height } \\
(\mathrm{cm})\end{array}$ & $\begin{array}{l}\text { Number of } \\
\text { leaves }\end{array}$ & $\begin{array}{c}\text { Leaf } \\
\operatorname{length}(\mathbf{c m})\end{array}$ & $\begin{array}{l}\text { Days to } \\
\text { flowering }\end{array}$ & $\begin{array}{l}\text { Spike length } \\
(\mathrm{cm})\end{array}$ & $\begin{array}{l}\text { Flower bud } \\
\text { length }(\mathrm{cm})\end{array}$ & $\begin{array}{c}\text { Flower } \\
\text { diameter } \\
(\mathrm{cm})\end{array}$ & $\begin{array}{c}\text { Number of flowers } \\
\text { per plant }\end{array}$ \\
\hline \multirow{2}{*}{$\begin{array}{l}\text { Plant } \\
\text { height }\end{array}$} & $\mathrm{G}$ & 1 & -0.404 & -0.283 & -0.109 & $-0.914 *$ & -0.474 & 0.471 & -0.442 \\
\hline & $\mathrm{P}$ & 1 & -0.091 & -0.076 & 0.103 & -0.320 & -0.415 & 0.405 & -0.314 \\
\hline \multirow{2}{*}{$\begin{array}{l}\text { No. of } \\
\text { leaves }\end{array}$} & G & & 1 & 0.195 & -0.052 & $-0.883 *$ & 0.725 & -0.358 & 0.243 \\
\hline & $\mathrm{P}$ & & 1 & 0.330 & 0.162 & -0.269 & 0.617 & -0.271 & 0.200 \\
\hline \multirow{2}{*}{$\begin{array}{l}\text { Leaf } \\
\text { length }\end{array}$} & G & & & 1 & $-0.818^{*}$ & -0.114 & -0.065 & -0.328 & 0.542 \\
\hline & $\mathrm{P}$ & & & 1 & -0.550 & 0.144 & -0.062 & -0.260 & 0.466 \\
\hline \multirow{2}{*}{$\begin{array}{c}\text { Days to } \\
\text { flowering }\end{array}$} & $\mathrm{G}$ & & & & 1 & -0.719 & -0.181 & -0.544 & $-0.811 *$ \\
\hline & $\mathrm{P}$ & & & & 1 & -0.228 & -0.159 & -0.413 & -0.612 \\
\hline \multirow{2}{*}{$\begin{array}{l}\text { Spike } \\
\text { length }\end{array}$} & $\mathrm{G}$ & & & & & 1 & 0.164 & 0.251 & 0.665 \\
\hline & $\mathrm{P}$ & & & & & 1 & 0.118 & 0.200 & 0.476 \\
\hline \multirow{2}{*}{$\begin{array}{c}\text { flower } \\
\text { bud length }\end{array}$} & G & & & & & & 1 & 0.193 & 0.561 \\
\hline & $\mathrm{P}$ & & & & & & 1 & 0.241 & 0.563 \\
\hline \multirow{2}{*}{$\begin{array}{c}\text { Flower } \\
\text { bud } \\
\text { diameter }\end{array}$} & G & & & & & & & 1 & 0.041 \\
\hline & $\mathrm{P}$ & & & & & & & 1 & 0.240 \\
\hline \multirow{2}{*}{$\begin{array}{c}\text { Number } \\
\text { of flowers } \\
\text { per plant }\end{array}$} & $\mathrm{G}$ & & & & & & & & 1 \\
\hline & $\mathrm{P}$ & & & & & & & & 1 \\
\hline
\end{tabular}


Table.3 Path analysis in Lilium

\begin{tabular}{|c|c|c|c|c|c|c|c|c|}
\hline S.No. & $\begin{array}{c}\text { Plant height } \\
\text { (cm) }\end{array}$ & $\begin{array}{c}\text { Number of } \\
\text { leaves }\end{array}$ & $\begin{array}{c}\text { Leaf } \\
\text { length }\end{array}$ & $\begin{array}{c}\text { Days to } \\
\text { flowering }\end{array}$ & $\begin{array}{c}\text { Spike } \\
\text { length } \\
\text { fom })\end{array}$ & $\begin{array}{c}\text { Flower bud } \\
\text { length }(\mathbf{c m})\end{array}$ & $\begin{array}{c}\text { Flower } \\
\text { diameter } \\
\text { (cm) }\end{array}$ & $\begin{array}{c}\text { Number of } \\
\text { flowers per } \\
\text { plant }\end{array}$ \\
\hline $\mathbf{1}$ & $\mathbf{1 . 0 3 5}$ & 1.268 & -0.741 & -0.155 & 0.301 & -1.860 & -0.291 & $\mathbf{- 0 . 4 4 2}$ \\
\hline $\mathbf{2}$ & -0.418 & $\mathbf{- 3 . 1 3 6}$ & 0.512 & -0.074 & 0.291 & 2.848 & 0.221 & $\mathbf{0 . 2 4 3}$ \\
\hline $\mathbf{3}$ & -0.293 & -0.613 & $\mathbf{2 . 6 1 9}$ & -1.157 & 0.038 & -0.255 & 0.202 & $\mathbf{0 . 5 4 2}$ \\
\hline $\mathbf{4}$ & -0.113 & 0.164 & -2.141 & $\mathbf{1 . 4 1 5}$ & 0.237 & -0.709 & 0.336 & $\mathbf{- 0 . 8 1 1}$ \\
\hline $\mathbf{5}$ & -0.946 & 2.769 & -0.299 & -1.018 & $\mathbf{- 0 . 3 3 0}$ & 0.643 & -0.155 & $\mathbf{0 . 6 6 5}$ \\
\hline $\mathbf{6}$ & -0.490 & -2.275 & -0.170 & -0.256 & -0.054 & $\mathbf{3 . 9 2 6}$ & -0.119 & $\mathbf{0 . 5 6 1}$ \\
\hline $\mathbf{7}$ & 0.488 & 1.123 & -0.858 & -0.770 & -0.083 & 0.759 & $\mathbf{- 0 . 6 1 8}$ & $\mathbf{0 . 0 4 1}$ \\
\hline
\end{tabular}

Residue $=0.1082$

The stalk length which is another important quality parameters significantly varied among asiatic cultivars. The spike length was highest in Tresor $(52.4 \mathrm{~cm})$ and the lowest in Black Out $(43.0 \mathrm{~cm})$. This variation in stalk length might be due to difference in the genetic make up of varities of lilium. Bud length $(19.9 \mathrm{~cm})$ and bud diameter $(17.7 \mathrm{~cm})$ was maximum in Tresor. Such varietal difference for sprouting has been also reported by Sindhu (2012). Cultivars; 'Tresor and Brunello' are found to be superior for producing more stem length, number of leaves/plant and number of flower buds/plant. This variation in flower stalk length might be due to difference in the genetic makeup of varieties of Lilium.

\section{Correlation}

The number of flowers per plant is the final product of many factors. The association of various yield components with yield could be assessed by computing correlation coefficients which could be useful for selection of desirable traits. Simple correlation co- efficient between growth, flower and yield characters in Lilium was analysed and is presented in table2.It is revealed that plant height showed negative effect on number of flowers per plant both at genotypic and phenotypic level.
In the present study, plant height had positive direct effect on flower diameter both at phenotypic and genotypic level and negative effect on number of leaves, leaf length, days to flowering, spike length, flower bud length and number of flowers per plant at genotypic level. But in contradictory, days to flowering showed positive correlation at phenotypic level.

Number of leaves showed positive direct effect on leaf length, bud length and number of flowers per bud at genotypic level. but, the leaf length, spike length, showed negative effect. Number of leaves showed positive indirect effect via leaf length, days to flowering and flower bud length at phenotypic level. This results are in accordance with the findings of Patra, and Mohanty. 2015. This also indicates that their positive and significant correlations at the phenotypic levels due to their high direct effects.

Leaf length showed negative effect on days to flowering, spike length, flower bud length, flower diameter and number of flowers per plant both at genotypic and phenotypic level. Similarly, days to flowering also showed negative effect on spike length, flower diameter and number of flowers per plant both at genotypic and phenotypic level. 
Similar results were reported by Anuradha (1990).Positive and highly significant phenotypic correlation of spike length with plant height and rachis length were mainly due to their respective high direct effects in gladiolus.

Spike length showed positive effect on flower bud length, flower diameter and number of flowers per plant both at phenotypic and genotypic level. Flower bud length showed positive effect on flower diameter and number of flowers per plant both at phenotypic and genotypic level. Flower bud diameter showed positive effect on number of flowers per plant both at phenotypic and genotypic level.

\section{Path analysis}

Path analysis is useful in unraveling these two effects and was first suggested by Wright (1921) and subsequently elaborated by $\mathrm{Li}$ (1956). This is simply a standardized partial regression analysis, which is based on cause and relationship, which serves to analyses by sub dividing correlation in a causal scheme. Dewey and Lu (1959) were perhaps the first to adopt this technique in the determination of yield components in crested wheat grass and they demonstrated the utility of this method in plant selection. Since then, it is being extensively utilized by plant scientists so as to get a clean picture of association of various plant characters. In this study, the residual effect of path analysis was 0.1082 . From this study, it was evident that the highest direct effect on 1-Plant height $(\mathrm{cm}), 2$ - Number of leaves, 3- Leaf length $(\mathrm{cm})$, 4- Days to flowering, 5- Spike length, 6- Flower bud length $(\mathrm{cm}), 7$ - Flower diameter

Path coefficient analysis has been used to organize the relationship between independent variable and responsible variables. To understand the direct and indirect effects of each character on flower yield, partitioning of correlation coefficient into direct and indirect effects through path coefficient analysis is very important. The data on direct and indirect effects of different characters on commercially important characters viz., number of leaves, leaf length, spike length, flower bud length, number of flowers per spike and floral diameter are presented in Tables.3.

Knowledge of degree of association of yield with its components is of great importance. because yield is not an independent character. But it is the resultant of the interactions of a number of component characters among them selves as well as with the environment in which the plant grows. Further each character is likely to be modified by action of genes present in the genotypes of plant and also by the environment and it becomes difficult to evaluate this complex character directly. Therefore, correlation study of yield with its component trait has been executed to find out the yield contributing traits.

Among all the characters studied spike length (0.665) showed highest positive direct effect on flower yield per plant followed by flower diameter (0.561), leaf length (0.542), number of leaves per plant (0.243) and flower bud length (0.041). Whereas negative direct effect was executed by plant height $(-0.442)$ and days to flowering (-0.811). The significant and positive correlations between different characters were previously reported by Sirohi (2000) and Maurya (2011). Residual effect was found to be (1.1082). Hence, spike length, flower diameter, leaf length, number of leaves per plant and flower bud length may be considered for further improvement.

The results is in accordance with Anuradha (1990) for rachis length. Misra and Saini(1990) for number of florets open at one time, plant height and weight of daughter corm in gladiolus. This results are in 
accordance with the findings of Patra, and Mohanty. 2015. This also indicates that their positive and significant correlations at the phenotypic levels due to their high direct effects.

Improvement in Lilium thus may be enhanced through the direct selection of genotypes to be used in breeding programmes for the above mentioned characters exhibiting high positive direct and indirect effects with positive correlations. While, intervarietal crossing programmes for the desired characters on the basis of the traits having negative direct effect ultimately results in a combination of characters.

\section{References}

Dhiman, M.R. (2003). Evaluation of hybrid lily under Kullu conditions. J. Ornam. Hort., 6(2): 154-155.

Dwibedi, Sanjai., K., Attrey, D. P., Eli Paljor and Kareem, Abdul (2002). Introduction and evaluation of Asiatic Lilium in cold arid conditions of Ladkh. Floriculture Research Trend in India. Proceedings of the National Symposium on Indian Floriculture in the new millennium, LalBagh, Banglore, 25-27 February, pp. 293-294.

Hertogh AD \& Nard ML (1993). The physiology of flower bulbs: A comprehensive treatise on the physiology and utilization of ornamental flowering bulbous and tuberous plants (Eds:. De Hertogh and Le Nard). Elsevier Science Publishers B.V., Molenwerf 1,
Amsterdam, The Netherlands 3-5.

Kumar R, Patel V, Verma D, Bidyut C Singh S. \& Sindhu S (2011). Evaluation of Asiatic lilium under subtropical mid hills of Meghalaya. Advance Research Journal of Crop Improvement, 2(2) 257259.

Mishra, H.P. (1997). Performance of gladiolus genotypes under calcareous soil for North Bihar. Indian J. Hort., 14(1): 77-92.

MC Rae EA (1998). Lilies. Timber Press, Poland.

Pandey, R.K., Dogra, Sheetal, Sharma, J.P. and Jamwal, Shivani (2008). Evaluation of Asiatic hybrid lily cultivars under subtropical conditions of Jammu region. J. Plant Sci. \& Res., 24(2): 213-214.

Sindhu SS, Singh JP \& Singh RK (2012). Evaluation of Lilium cultivars under northern plains. International Journal of Agricultural Sciences, 8(2) 460-461.

Srinivas, M. (2002). Response of Asiatic lilies to open cultivation. Abstract, National Symposium on Indian Floriculture in the New Millennium. Feb.25-27, 50-51.

Srinivas, M. (2003). Performance of Lilium under Bangalore condition. Abstract, National Symposium on Recent Advances in Indian Floriculture. Nov, 12-14, 17.

Wilfret GJ and Raulston JC (1971). Evaluation of Eater lily \& Hybrid lily cultivars for commercial flower production in Florida. IFAS Agricultural Research \& Education Centre Bradenton 359-363.

\section{How to cite this article:}

Sankari, A., M.Anand, B. Anita and Swarna Priya, R. 2020. Correlation and Coefficient Studies in Lilium (Lilium spp.). Int.J.Curr.Microbiol.App.Sci. 9(02): 3073-3079. doi: https://doi.org/10.20546/ijcmas.2020.902.354 